\title{
The Southern Divide: Testing morphological differences among bifacial points from southern and southeastern Brazil using geometric morphometrics
}

\author{
Mercedes Okumura ${ }^{1}$, Astolfo G. M. Araujo ${ }^{2}$ \\ 1. PPGArq, Department of Anthropology, National Museum, Federal University of Rio de Janeiro, Brazil. \\ Email: mercedes@mn.ufrj.br \\ 2. Museum of Archaeology and Ethnology, University of São Paulo, Brazil. Email: astwolfo@usp.br
}

\begin{abstract}
:
Bifacial points have been used to characterize the "Umbu" tradition in southern and southeastern Brazil. This archaeological tradition has been related to sites dated from the late Pleistocene-early Holocene boundary to near historical times. Such a huge temporal range and vast territory have suggested the existence of greater diversity within this tradition that has been ignored thus far due to the lack of systematic regional studies of such points. Through geometric morphometric analysis, this article aims to test the hypothesis that there are substantial differences in the Holocene bifacial points associated with the Umbu tradition in southeastern Brazil. Five landmarks were digitized in standardized photographs from 658 points from the states of São Paulo, Paraná, Santa Catarina, and Rio Grande do Sul. The results show that points made by groups from southeastern Brazil (São Paulo state) present a very distinct morphology (size and shape) in comparison to those made by the southern groups (Paraná, Santa Catarina and Rio Grande do Sul). This would indicate a regional identity shared only by some groups from São Paulo (at least regarding the projectile points). It is possible that Umbu tradition presents a more restricted range, both in chronological and spatial terms, than the one proposed so far.
\end{abstract}

Keywords: lithics; Umbu tradition; Pleistocene-Holocene boundary; projectile points

\section{Introduction}

Flaked lithic artifacts shaped as projectile points are quite common in the Americas, being generically called "arrowheads" or "projectile points". Although their piercing or puncturing function is obvious, there are different ways in which such piercing or drilling can be carried out (Cattelain 1997): pressure-induced muscle strength of those handling the artifact directly transmitted via a shaft (thrusting spear), pressure-induced shock between the artifact and the target, being the kinetic energy released by either a bow or a dart thrower. It is known that stone artifacts that look like points can also be used as awls, knives, spears, harpoons, among other uses (Pitt Rivers 1906: 101, 117; Fenenga 1953; Rausing 1967: 164; Kay 1996; Greaves 1997; Erlandson et al. 2014). In short, the terms "arrowhead" or

Published by the School of History, Classics and Archaeology, University of Edinburgh ISSN: 2055-0472. URL: http://journals.ed.ac.uk/lithicstudies/

This work is licensed under a Creative Commons Attribution 2.5 UK: Scotland License. 
"projectile point" are inadequate, since they presuppose the use of a specific device to transmit the energy (For a recent review on the potential propulsion systems associated to bifacial points from southern and southeastern Brazil, see Okumura 2015 and Okumura \& Araujo 2015a). Therefore, in this article, we will designate such artifacts as "bifacial points". An important feature of bifacial points lies in the fact they are formal artifacts, i.e. instruments whose manufacture aims to obtain a specific patterned form.

In the 1970s, Brazilian archaeologists tried to understand the morphological diversity observed in bifacial points through the use of typologies and the creation of archaeological phases (see Table 1). Miller (1967; 1974), working in the Sinos Valley and Maquiné region (Rio Grande do Sul), created three pre-ceramic phases that presented bifacial points: Camuri, Umbu, and Itapuí. The Camuri Phase was characterized by open-air sites, while Umbu and Itapuí Phases were associated with rockshelters. Umbu would be more ancient (6000 to 4000 years BP) than Itapuí, and the predominant bifacial point type would be stemmed points with triangular bodies, as well as lanceolated points. Itapuí Phase would be more recent than Umbu (4000 to 1000 years BP), being characterized by points with bifurcated stem and triangular body, sometimes presenting serrated edges.

Another attempt to classify sites presenting bifacial points was the creation of the Bituruna tradition (Chmyz 1981a), which was tentatively associated to Paleoindian sites, where large stemmed bifacial leaf-shaped points were abundant. This tradition was identified in the middle and low Iguaçu River, in central-southern and south-western Paraná state, as well as in the areas near powerplants in Foz do Areia, Salto Santiago and Salto Caxias (Chmyz 1969; 1981a; b; Parellada 1999). However, the alleged antiquity of this tradition still remains to be verified; thus far, dates are scarce. The only radiocarbon age concerning this tradition comes from the site Jusante UHE Salto Caxias I, in south-western Paraná, presenting a date of $4810 \pm 360$ BP (Australian National University-ANU 192-19; Parellada 2005: 30).

Many other archaeological phases presenting bifacial points have been identified in southern Brazil (Iguaçu and Potinga Phases; Chmyz 1969; Vinitu Phase; Kern 1981: 215-220; Schmitz 1984: 12-14; 1991a; Itaguajé Phase; Chmyz \& Chmyz 1986; Itaió Phase; Piazza 1974; Capivara Phase; Schmitz 1991a). Despite these early efforts to sort out the morphological diversity observed in the bifacial points from southern Brazil, the lack of good chronologies and the unclear definitions for the bifacial point classes (sensu Dunnell 1971: 45) led to difficulties in assigning new sites to these "phases", resulting in a later lumping of them into a single "tradition", Umbu.

The Umbu tradition would present its oldest phase in southwestern Rio Grande do Sul with the Uruguai Phase, in the $11^{\text {th }}$ Millenium BP (Kern 1981: 232-8; Schmitz 1987) (see Table 1). A more recent revision of the sites and dates by Dias \& Jacobus (2003) considers only ten sites with a chronology ranging from 10,800 to $8500 \mathrm{BP}$. If we accept the revised data, Uruguai Phase would be contemporaneous to Umbu, since the oldest date for Uruguai Phase is $10,985 \pm 100 \mathrm{BP}$ (Laranjito Site, see Table 1). According to Schmitz (1978: 108), the Uruguai Phase would be the beginning of a tradition presenting bifacial points that would continue until the $14^{\text {th }}$ Century with the name Umbu (while Schmitz (1978: 108) supports the idea that Uruguai Phase would represent the beginnings of Umbu tradition, other authors, like Hilbert (1991: 16), consider that Uruguai Phase would be followed by Umbu tradition. Schmitz (1978:112) also notes the similarity among bifacial points from Uruguay, Missiones (Argentina) and Southern Brazil. Schmitz (1987) draws attention to the fact that, despite the large number of sites identified as representatives of Umbu tradition very few chronological indicators have been identified so far.

This eventually generated controversy concerning the existence of such a tradition, since it would encompass a very extensive chronological range, from 11,000 to 500 years BP. Therefore, Umbu tradition poses a special problem to archaeologists because of two basic 
characteristics: its wide geographic distribution and, above all, the length of its chronology. Researchers have questioned whether identification of a tradition extending from the Pleistocene-Holocene period until the eve of the historical period is plausible. Such doubts have led to the discussion of the validity of the concept of "Umbu tradition" in terms of classification and organization. Given the lack of identifiable chronological markers, this tradition became, in practice, "defined" only by the presence of bifacial points, becoming synonymous with "sites presenting bifacial points", regardless of their chronology or geographic location.

Currently, this tradition, dispersed throughout southern and southeastern Brazil, is simply characterized by the presence of bifacial points, presenting dates ranging from the Late Pleistocene to historical times (Schmitz et al. 1980; Schmitz 1999; Noelli 2000). Therefore, throughout the years, all archaeological sites presenting bifacial points, from Rio Grande do Sul to São Paulo (and in some cases including more northern settings, like Minas Gerais, (Koole 2007; 2014) and Mato Grosso do Sul, (Kashimoto \& Martins 2009; Martins \& Kashimoto 2012)), ended up being classified as belonging to the Umbu tradition. For example, in the case of São Paulo state, Miller Jr. (1972) defined the Rio Claro tradition (based on sites from Rio Claro, São Paulo state) as presenting bifacial points in some phases. Schmitz (1978: 120; 1991) also remarked the differences between the material from Rio Claro and Uruguai Phase, considering the bifacial points from Rio Claro as a regional evolution of Umbu tradition. Later, Prous (1991: 154) reports that this tradition would have been subsumed within Umbu tradition. This inclusion appears to be quite controversial since not all phases of the Rio Claro tradition presented bifacial points, and thus theoretically it could not be included in Umbu tradition. Regardless of the adequacy of this tradition, it is likely that such direct association have been obliterating important regional and local variations, either in chronological or spatial terms. To this date, regardless of the name given by archaeologists, it is possible to say there is a substantial number of archaeological sites in southern and southeast Brazil presenting bifacial points dating from the Late Pleistocene to the eve of the historical period (Table 1 and Figure 1). 
Table 1: Archaeological sites from southern and southeastern Brazil presenting bifacial points dated from the Late Pleistocene to the eve of the historical period. The column "number on map" refers to the map presented in Figure 1.

\begin{tabular}{|c|c|c|c|c|c|c|c|c|}
\hline Years BP & Site & Lab Number & Region & State & Reference & $\begin{array}{c}\text { Map } \\
\text { Number }\end{array}$ & Phase & Phase Reference \\
\hline $3100 \pm 50$ & Gruta do Marinheiro & Beta 230979 & Pains & MG & Koole 2007:107 & 1 & & \\
\hline $9610 \pm 60$ & Gruta do Marinheiro & Beta 230980 & Pains & MG & Koole 2007:107 & 1 & & \\
\hline $4650 \pm 170$ & Camargo & - & Piraju & SP & Pallestrini \& Chiara 1978 & 2 & & \\
\hline $1250 \pm 50$ & BS22 & Gif 9993 & Bairro da Serra & SP & DeBlasis 1996:81 & 3 & & \\
\hline $5540 \pm 120$ & Sarandi & Gif & Guareí & SP & Caldarelli 1983:115 & 4 & & \\
\hline 9540 & Bela Vista I & - & Mogi Mirim & SP & Documento Ltda. 2003 & 5 & & \\
\hline $6090 \pm 40$ & Capelinha I & Beta 184619 & Cajati & SP & Plens 2007:74 & 6 & & \\
\hline $8860 \pm 60$ & Capelinha I & Beta 153988 & Cajati & SP & Neves et al. 2005 & 6 & & \\
\hline $8795 \pm 100$ & Capelinha I & A11239 & Cajati & SP & Neves et al. 2005 & 6 & & \\
\hline $8500 \pm 100$ & Capelinha I & A11236 & Cajati & SP & Neves et al. 2005 & 6 & & \\
\hline $9250 \pm 50$ & Capelinha I & Beta 189331 & Cajati & SP & Plens 2007:74 & 6 & & \\
\hline $\begin{array}{l}10500 \\
\pm 1500\end{array}$ & Capelinha I & $\begin{array}{l}\text { Nucleo } \\
\text { Bras/BH }\end{array}$ & Cajati & SP & Collet 1985 & 6 & & \\
\hline $8870 \pm 50$ & Carcará & Beta 303991 & São José dos Campos & SP & Juliani 2012:29-30 & 7 & & \\
\hline $7.680 \pm 40$ & Alice Boer & Beta 320199 & Rio Claro & SP & Araujo 2012 & 8 & & \\
\hline $7.200 \pm 40$ & Alice Boer & Beta 320198 & Rio Claro & SP & Araujo 2012 & 8 & & \\
\hline $3705 \pm 130$ & Céu Azul I & SI 1575 & São José dos Pinhais & PR & Schmitz 1984:47 & 9 & Céu Azul & Schmitz 1984:47 \\
\hline $755 \pm 60$ & Céu Azul I & SI 1578 & São José dos Pinhais & $\mathrm{PR}$ & Schmitz 1984:47 & 9 & Céu Azul & Schmitz 1984:47 \\
\hline $730 \pm 50$ & PR-UV-02 Bogugeski & SI 142 & União da Vitória & PR & Schmitz 1978 & 10 & Iguaçu & Schmitz 1978 \\
\hline $3110 \pm 140$ & PR-UV-04 Kavales & SI 802 & União da Vitória & PR & Chmyz 1977:197 & 10 & Iguaçu & Chmyz 1977 \\
\hline $990 \pm 190$ & Fazenda Marrecas & ANU 192-26 & Dr. Ulysses & PR & Parellada 2005:34 & 11 & & \\
\hline $4350 \pm 250$ & Fazenda Marrecas & ANU 192-25 & Dr. Ulysses & PR & Parellada 2005:34 & 11 & & \\
\hline $9040 \pm 400$ & Ouro Verde 1 & ANU 192-17 & Boa Esperança do Iguaçu & PR & Parellada 2005:34 & 12 & & \\
\hline $6240 \pm 250$ & $\begin{array}{l}\text { Toninho da } \\
\text { Recapadora }\end{array}$ & ANU 192-18 & Boa Vista da Aparecida & PR & Parellada 2005:34 & 13 & & \\
\hline $8115 \pm 80$ & PR-NL-8 & SI 6401 & Baixo Paranapanema & PR & $\begin{array}{l}\text { Dias \& Jacobus 2003; } \\
\text { Chmyz \& Chmyz } 1986\end{array}$ & 14 & Itaguajé & Chmyz \& Chmyz 1986 \\
\hline
\end{tabular}




\begin{tabular}{|c|c|c|c|c|c|c|c|c|}
\hline Years BP & Site & Lab Number & Region & State & Reference & $\begin{array}{c}\text { Map } \\
\text { Number }\end{array}$ & Phase & Phase Reference \\
\hline 6715 & PR-AP-45 & SI 6498 & Baixo Paranapanema & PR & Chmyz \& Chmyz 1986 & 14 & Itaguajé & Chmyz \& Chmyz 1986 \\
\hline $9630 \pm 40$ & PR-WB-16 ASR Tunas & Beta 210872 & Arapoti & PR & Chmyz et al. 2008 & 15 & & \\
\hline $7170 \pm 60$ & PR-WB-16 ASR Tunas & Beta 210871 & Arapoti & PR & Chmyz et al. 2008 & 15 & & \\
\hline $4035 \pm 150$ & PR-FI-43 & SI 5044 & Foz do Iguaçu & PR & Chmyz 1983:100 & 16 & & \\
\hline $660 \pm 80$ & SC-VI-10 & SI 537 & Presidente Getúlio & SC & Schmitz et al. 2009 & 17 & Itaió & Piazza 1974 \\
\hline $290 \pm 80$ & SC-VI-10 & SI 536 & Presidente Getúlio & SC & Schmitz et al. 2009 & 17 & Itaió & Piazza 1974 \\
\hline $905 \pm 95$ & $\begin{array}{l}\text { RS-MJ-53-AyB Aleros } \\
\text { de la Lihna Setima }\end{array}$ & SI 1196 & Rio Jacuí & RS & $\begin{array}{l}\text { Brochado \& Schmitz } \\
1973\end{array}$ & 18 & Rio Pardinho & Schmitz 1984:47 \\
\hline $800 \pm 40$ & $\begin{array}{l}\text { RS-SM-7 Alero de la } \\
\text { Pedra Grande }\end{array}$ & SI 1003 & São Pedro do Sul & RS & $\begin{array}{l}\text { Brochado \& Schmitz } \\
1973\end{array}$ & 19 & & \\
\hline $605 \pm 40$ & $\begin{array}{l}\text { RS-SM-7 Alero de la } \\
\text { Pedra Grande }\end{array}$ & SI 1002 & São Pedro do Sul & RS & $\begin{array}{l}\text { Brochado \& Schmitz } \\
1973\end{array}$ & 19 & Rio Pardinho & Schmitz 1984:47 \\
\hline $\begin{array}{l}11555 \\
\pm 230\end{array}$ & RS-IJ-68 & SI 3750 & São Borja & RS & Miller 1987 & 20 & Uruguai & Miller 1987 \\
\hline $\begin{array}{l}10810 \\
\pm 275\end{array}$ & $\begin{array}{l}\text { RS-I-66 Milton } \\
\text { Almeida }\end{array}$ & SI 2622 & Uruguaiana & RS & Politis 2008 & 21 & Uruguai & Dias \& Jacobus 2003 \\
\hline $\begin{array}{l}10985 \\
\pm 100\end{array}$ & RS-I-69 Laranjito & SI 2630 & Uruguaiana & RS & Miller 1987 & 21 & Uruguai & Miller 1987 \\
\hline $\begin{array}{l}10800 \\
\pm 150\end{array}$ & RS-I-69 Laranjito & N 2523 & Uruguaiana & RS & Miller 1987 & 21 & Uruguai & Miller 1987 \\
\hline $\begin{array}{l}10400 \\
\pm 110\end{array}$ & RS-I-69 Laranjito & N 2521 & Uruguaiana & RS & Miller 1987 & 21 & Uruguai & Miller 1987 \\
\hline $10240 \pm 80$ & RS-I-69 Laranjito & SI 3106 & Uruguaiana & RS & Miller 1987 & 21 & Uruguai & Miller 1987 \\
\hline $\begin{array}{l}10200 \\
\pm 125\end{array}$ & RS-I-69 Laranjito & N 2522 & Uruguaiana & RS & Miller 1987 & 21 & Uruguai & Miller 1987 \\
\hline $9620 \pm 110$ & RS-I-69 Laranjito & SI 2631 & Uruguaiana & RS & Miller 1987 & 21 & Uruguai & Miller 1987 \\
\hline $9120 \pm 340$ & RS-I-70 Imbaá I & SI 2632 & Uruguaiana & RS & Miller 1987 & 21 & Uruguai & Miller 1987 \\
\hline $\begin{array}{l}10180 \\
\pm 275\end{array}$ & RS-I-98 & SI 3752 & Uruguaiana & RS & Miller 1987 & 21 & Uruguai & Miller 1987 \\
\hline $610 \pm 65$ & RS-314 & SI 1195 & Uruguaiana & RS & $\begin{array}{l}\text { Brochado \& Schmitz } \\
1973\end{array}$ & 21 & Uruguaiana & Schmitz 1987 \\
\hline $9450 \pm 115$ & RS-I-72 Palmito 2 & SI 2634 & Uruguaiana & RS & Miller 1987 & 21 & Uruguai & Miller 1987 \\
\hline
\end{tabular}




\begin{tabular}{|c|c|c|c|c|c|c|c|c|}
\hline Years BP & Site & Lab Number & Region & State & Reference & $\begin{array}{c}\text { Map } \\
\text { Number }\end{array}$ & Phase & Phase Reference \\
\hline $9855 \pm 130$ & RS-IJ-67 Pessegueiro & SI 3749 & Itaqui & RS & Miller 1987 & 22 & Uruguai & Miller 1987 \\
\hline $8585 \pm 115$ & RS-IJ-67 Pessegueiro & SI 2636 & Itaqui & RS & Miller 1987 & 22 & Uruguai & Dias \& Jabocus 2003 \\
\hline $9430 \pm 360$ & RS-TQ-58 Garivaldino & Beta 44739 & Montenegro & RS & Ribeiro \& Ribeiro 1999 & 23 & & \\
\hline $8290 \pm 130$ & RS-TQ-58 Garivaldino & Beta 32183 & Montenegro & RS & Ribeiro et al. 1989 & 23 & & \\
\hline $8020 \pm 150$ & RS-TQ-58 Garivaldino & Beta 33458 & Montenegro & RS & Ribeiro \& Ribeiro 1999 & 23 & & \\
\hline $7250 \pm 350$ & RS-TQ-58 Garivaldino & Beta 44740 & Montenegro & RS & Ribeiro \& Ribeiro 1999 & 23 & & \\
\hline $6760 \pm 50$ & RS-TQ-58 Garivaldino & Beta 226135 & Montenegro & RS & Rosa 2009 & 23 & & \\
\hline $5655 \pm 140$ & $\begin{array}{l}\text { RS-C-14 Bom Jardim } \\
\text { Velho }\end{array}$ & SI 1199 & São Sebastião do Caí & RS & Dias 2003:112 & 23 & Itapuí & Chmyz 1981b \\
\hline $745 \pm 115$ & $\begin{array}{l}\text { RS-C-14 Bom Jardim } \\
\text { Velho }\end{array}$ & SI 1198 & São Sebastião do Caí & RS & Dias 2012 & 23 & & $\begin{array}{l}\text { Brochado \& Schmitz } \\
1973\end{array}$ \\
\hline $8430 \pm 50$ & RS-C-61 Adelar Pilger & Beta 260455 & São Sebastião do Caí & RS & Dias \& Neubauer 2010 & 23 & & \\
\hline $8150 \pm 50$ & RS-C-61 Adelar Pilger & Beta 260456 & São Sebastião do Caí & RS & Dias 2012 & 23 & & \\
\hline $8030 \pm 50$ & RS-C-61 Adelar Pilger & Beta 229583 & São Sebastião do Caí & RS & Dias 2012 & 23 & & \\
\hline $6180 \pm 50$ & RS-C-61 Adelar Pilger & Beta 227856 & São Sebastião do Caí & RS & Dias 2012 & 23 & & \\
\hline $3000 \pm 40$ & RS-C-61 Adelar Pilger & UGA 02017 & São Sebastião do Caí & RS & Dias 2012 & 23 & & \\
\hline $630 \pm 205$ & RS-C-12 Virador & SI 1201 & São Sebastião do Caí & RS & Dias 2012 & 23 & & $\begin{array}{l}\text { Brochado \& Schmitz } \\
1973\end{array}$ \\
\hline $7800 \pm 50$ & $\begin{array}{l}\text { RS-217 Pedro } \\
\text { Fridolino Schmitz }\end{array}$ & Beta 204345 & Bom Princípio & RS & Schmitz 2010 & 23 & & \\
\hline $1400 \pm 40$ & $\begin{array}{l}\text { RS-217 Pedro } \\
\text { Fridolino Schmitz }\end{array}$ & Beta 211727 & Bom Princípio & RS & Schmitz 2010 & 23 & & \\
\hline $2920 \pm 120$ & $\begin{array}{l}\text { RS-RP-86 Jandor } \\
\text { Hanssen }\end{array}$ & SI 4795 & Santa Cruz do Sul & RS & Ribeiro 1983 & 24 & Rio Pardinho & \\
\hline $1425 \pm 115$ & $\begin{array}{l}\text { RS-RP-81 Anápio de } \\
\text { Oliveira A }\end{array}$ & SI 4168 & Vera Cruz & RS & Ribeiro 1983 & 24 & & \\
\hline $5950 \pm 190$ & RS-LN-1 Dalpiaz & SI 234 & Osório & RS & Miller 1974 & 25 & Umbu & Miller 1974 \\
\hline $5680 \pm 240$ & RS-LN-1 Dalpiaz & SI 235 & Osório & RS & Miller 1974 & 25 & Umbu & Miller 1974 \\
\hline $4280 \pm 180$ & RS-LN-1 Dalpiaz & SI 233 & Osório & RS & Miller 1974 & 25 & Umbu & Miller 1974 \\
\hline $8790 \pm 40$ & RS-S-327 Sangão & Beta 160845 & Santo Antônio da Patrulha & RS & Dias 2012 & 26 & & \\
\hline
\end{tabular}




\begin{tabular}{|c|c|c|c|c|c|c|c|c|}
\hline Years BP & Site & Lab Number & Region & State & Reference & $\begin{array}{c}\text { Map } \\
\text { Number }\end{array}$ & Phase & Phase Reference \\
\hline $7390 \pm 40$ & RS-S-327 Sangão & Beta 154353 & Santo Antônio da Patrulha & RS & Dias 2012 & 26 & & \\
\hline $4690 \pm 40$ & RS-S-327 Sangão & Beta 154352 & Santo Antônio da Patrulha & RS & Dias 2012 & 26 & & \\
\hline $4610 \pm 140$ & RS-S-327 Sangão & Beta 160847 & Santo Antônio da Patrulha & RS & Dias 2012 & 26 & & \\
\hline $4160 \pm 10$ & RS-S-327 Sangão & Beta 154351 & Santo Antônio da Patrulha & RS & Dias 2012 & 26 & & \\
\hline $3970 \pm 40$ & RS-S-327 Sangão & Beta 160849 & Santo Antônio da Patrulha & RS & Dias 2012 & 26 & & \\
\hline $3730 \pm 60$ & RS-S-327 Sangão & Beta 160846 & Santo Antônio da Patrulha & RS & Dias 2012 & 26 & & \\
\hline $7240 \pm 40$ & RS-S-337 Monjolo & Beta 165626 & Santo Antônio da Patrulha & RS & Dias 2012 & 26 & & \\
\hline $6215 \pm 30$ & RS-S-337 Monjolo & KIA 20841 & Santo Antônio da Patrulha & RS & Dias 2012 & 26 & & \\
\hline $5230 \pm 40$ & RS-S-337 Monjolo & Beta 165625 & Santo Antônio da Patrulha & RS & Dias 2012 & 26 & & \\
\hline $520 \pm 70$ & RS-S-337 Monjolo & Beta 165623 & Santo Antônio da Patrulha & RS & Dias 2012 & 26 & & \\
\hline $440 \pm 90$ & RS-S-337 Monjolo & Beta 165621 & Santo Antônio da Patrulha & RS & Dias 2012 & 26 & & \\
\hline $1740 \pm 65$ & RS-S-359 Aterrado & SI 2344 & Santo Antônio da Patrulha & RS & Dias 2012 & 26 & Itapuí & Schmitz 1987 \\
\hline $920 \pm 40$ & $\begin{array}{l}\text { RS-S-360 } \\
\text { Marimbondo }\end{array}$ & Beta 154354 & Santo Antônio da Patrulha & RS & Dias 2012 & 26 & & \\
\hline $575 \pm 80$ & $\begin{array}{l}\text { RS-S-308 Morro da } \\
\text { Flecha } 1\end{array}$ & SI 804 & São Francisco de Paula & RS & $\begin{array}{l}\text { Brochado \& Schmitz } \\
1973\end{array}$ & 27 & Camuri & $\begin{array}{l}\text { Brochado \& Schmitz } \\
1973\end{array}$ \\
\hline
\end{tabular}




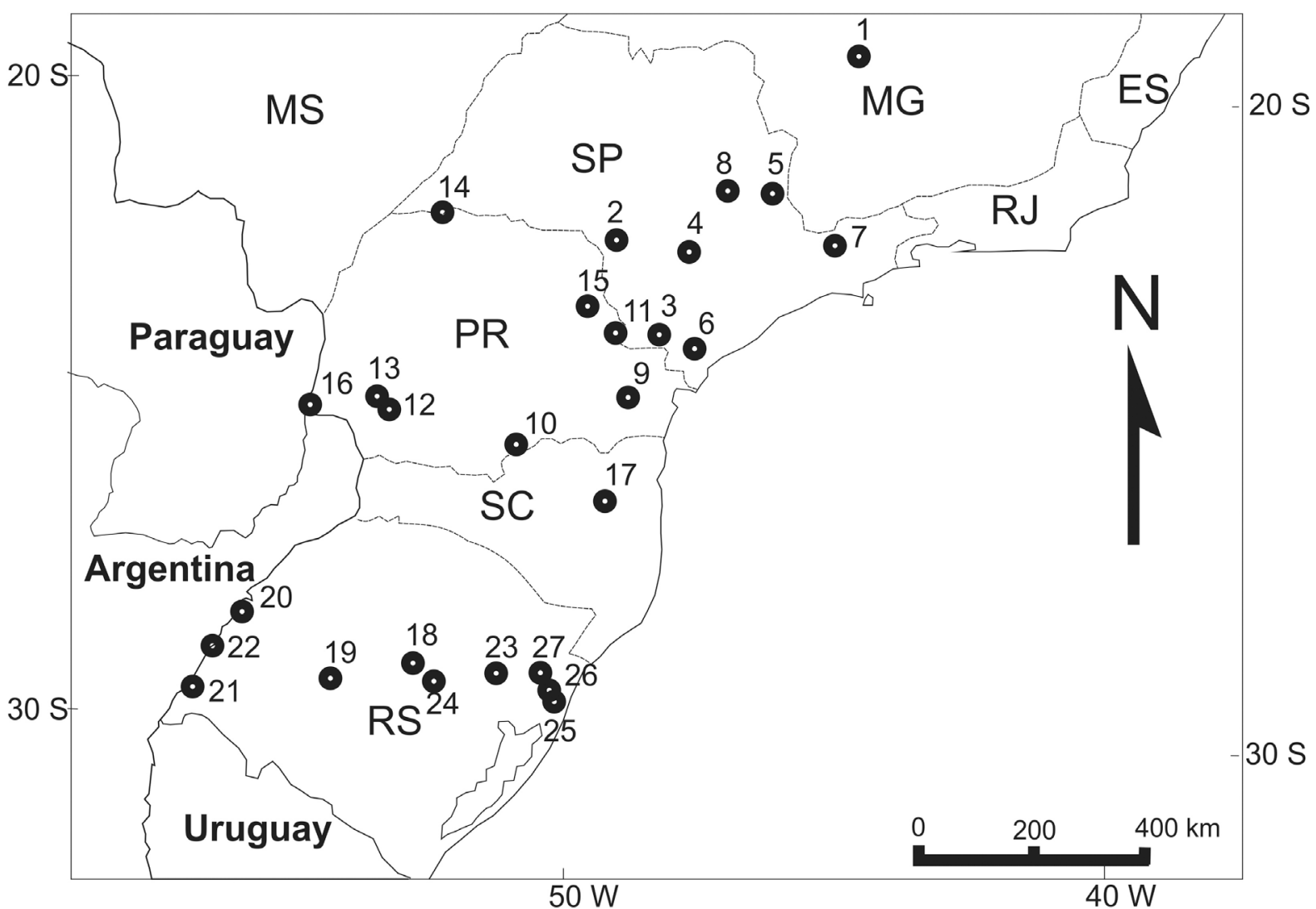

Figure 1: Archaeological sites from southern and southeastern Brazil presenting bifacial points dated from the Late Pleistocene to the eve of the historical period. The numbers refer to the column "map number" in Table 1.

\subsection{Classification and the problems of assigning archaeological materials into "archaeological traditions"}

The origins of the concepts of "phase" and "tradition" can be attributed to the Midwestern Taxonomic Method, by which North American archaeologists in the 1930s (McKern 1939) tried to define (or replace) the concept of “archaeological culture”. Decades later, a similar system was proposed by Phillips and Willey (1953), in the 1950s and partially adopted in Brazil by "The National Program of Archaeological Research" (PRONAPA Programa Nacional de Pesquisas Arqueológicas) in the 1970s. According to PRONAPA (Chmyz \& PRONAPA 1976: 145), a tradition is defined as "a group of elements or techniques that are distributed with temporal persistence." In principle, this concept was totally disconnected from any "ethnographic" meaning (similar to that proposed by the Midwestern Taxonomic Method). Archaeological research pioneers aimed at defining traditions, which was often done from the study of only one or two sites. Later, phases and traditions began to be compared to "autonomous and semi-autonomous units" or "tribes" ("phases”), “tribal or linguistic entities” and "nations” (“traditions” - Meggers \& Evans 1985; Schmitz 1991b).

In Brazil, criticisms of the definition and use of the term "tradition" pointed out three major shortcomings (Dias 2003: 51; Dias 2007; Dias \& Hoeltz 2010; Hilbert 1994; Milder 1999): 1) a definition of such traditions was based on a few typological criteria, 2) the use of a fossil guide to determine the association of a particular site to a tradition and 3) the use of few attributes for classification of a site in a tradition. In other words, the application of the term "tradition" resulted, for example, in all sites presenting bifacial points (which are the fossil guides of Umbu tradition) being automatically classified as belonging to the Umbu tradition, regardless of the morphology, chronology, geographic location, or type of site. 
After more than four decades since the initial definitions were proposed by PRONAPA, there were subsequent criticisms, followed by the remodeling of the "Pronapian" concepts, seeking stronger ties with anthropology, followed again by new waves of criticism, and finally today we have the crystallization of the concept of "tradition", simply because there is nothing better to replace it. After 40 years of controversy, perhaps we can be at peace with the term "tradition", as long as we understand it as a heuristic tool. Indeed, perhaps the best definition of tradition is the original one: simply a "group of elements or techniques that are distributed with temporal persistence". Fortunately, such definition refers to a group (a cluster of elements that can be listed) rather than a class, which would require a definition (Dunnell 1971: 45). Thus, the traditions will never be defined, only described. This may be unsatisfactory from a formal point of view, but again, perfectly serves our heuristic purposes.

Therefore, we do not propose abolishing the use of the term "Umbu tradition". However, we want to emphasize the importance of recognizing a morphological diversity present in these bifacial points that has been ignored so far. Traditions, or whatever name we give to these aggregate of phenomena, can be useful in terms of transmission of information among professionals and even among the laymen. However, they can be harmful (not to mention useless), when they ignore the observed variation by simply lumping together different classes of artifacts. In this context, we believe that the (ab)use of the term "Umbu tradition" must undergo further reflection.

\subsection{Why study bifacial points? Formal artifacts and their potential statistical approaches}

Binford $(1977$; 1979) suggested that technological organization could be seen as a continuum between cases centered on the production of highly modified ("curated") tools and cases where the tools are made from slightly modified raw materials ("expedient"). However, a quick review of the literature clearly points to a greater emphasis on characterization and study of formal lithic industries, whether in the Old World or the New World. Certainly, there is still a fascination for the formal lithic industries, reminiscent of collecting and curio cabinets, since these artifacts are more visually and aesthetically appealing, besides being more easily recognized as proper artifacts. Another important point is that, based on the discussions on style and function (Binford 1977; 1979; Dunnell 1978; Sackett 1985; among others), formal artifacts are more easily "seized" as conveying cultural transmission processes. This led to the development of various systems of classification, resulting in a greater availability of statistical analysis that can be applied in order to characterize such industries. This is the case in Europe and North America, for example, where the emphasis is on the variation between "types" of formal artifacts, which are generally considered independent of the technology. This emphasis has been the hallmark of the lithic analysis developed by François Bordes (1950), and this perspective has permeated the archaeological thought far beyond its original application in Middle Paleolithic European assemblages. Currently, many archaeologists may not share the fundamental ideas of Bordes, which sought to determine ethnicity and social interaction between different cultures, but still shape and technique are considered independent entities (Draper 1985). Thus, one cannot ignore the explanatory potential of formal artifacts, since this characteristic, the standardization of gestures and techniques aimed at producing artifacts with specific forms, allows the tracing of cultural interactions.

According to Dias (2003: 225), a lithic industry can only be fully understood with the analysis of the entire operational chain, and the typological variation observed in formal artifacts is just the tip of the iceberg (Perlés 1992: 223-224). However, what is proposed in this article is not an in-depth study of lithic technology itself, but the presentation of a 
complementary approach, involving the use of geometric morphometrics and multivariate statistical tests not very often used in Brazilian archaeology (but see Okumura \& Araujo 2014), but whose potential has been exploited successfully in several studies abroad (Saragusti et al. 2005; Cardillo 2006; 2009; 2010; Buchanan et al. 2007; Castiñeira et al. 2009; 2011; 2012; Franco et al. 2009; Archer \& Braun 2010; Buchanan \& Collard 2010; Costa 2010; Lycett et al. 2010; Iovita 2011; Brown et al. 2012; Charlin \& González-José 2012; Lycett \& Von Cramon-Taubadel 2012; Thulman 2012; Wang et al. 2012; de Azevedo et al. 2013; Lycett \& Eren 2013; Charlin et al. 2014; Davis et al. 2015; Fox 2015; Cardillo et al. in press). The use of multivariate statistical methods applied to geometric morphometrics data might help elucidate old questions about the characterization of the Umbu tradition, possibly clarifying the meanings related to changes in the morphology of bifacial points over time, the chrono-spatial relationships among different sets of points, among other issues. In this article, we will be focusing on testing the hypothesis that there are important differences in the morphology of Holocene bifacial points associated with the Umbu tradition in southeastern Brazil. Preliminary results regarding this sample have been previously published (Okumura \& Araujo 2013).

\section{Materials and methods}

\subsection{Geometric morphometrics: An overview}

The analysis of the morphology has always played an important role in different areas of knowledge, including biology, arts, and engineering, among others. Differences in morphology can be briefly described through familiar objects such as geometrical shapes or letters of the alphabet. However, such descriptions are rather vague, inaccurate or even erroneous, especially when the shapes are complex (Zelditch et al. 2004: 1) and when an appropriate morphometric approach is not applied. Although approaches using linear measures are often used to characterize the morphology of formal artifacts, it is well known that important information, especially regarding the shape (in comparison to size) is lost (Zelditch et al. 2004: 5). In order to avoid losing information on the form (constituted by shape and size), we conducted an analysis using Geometric Morphometrics (GMM).

GMM "is a disparate set of techniques with a common purpose: the statistical analysis of differences in form using a quantitative description that preserves the geometry of shape variation" (Viscosi \& Cardini 2011: 3). This preservation allows the visualization of group and individual differences. In this sense, taking the form, it is possible to separate size from shape, to quantify shape and to test differences among shapes (Bookstein 1991). The data obtained using GMM are coordinates of shape landmarks, whereas the traditional morphometrics deals with distances between landmarks. Therefore, GMM aims to quantify the differences in morphology through the use of landmarks (Bookstein 1991). Landmarks can be defined as "samples of discrete points which correspond among all the forms of a data set” (Rohlf \& Bookstein 1990: 63) or "discrete (...) loci that can be recognized as the same loci in all specimens in the study" (Zeldich et al. 2004: 23). The latter definition implies landmarks in a biological context. According to Zeldich et al. (2004: 24), landmarks should not change their topological positions relative to other landmarks (a one-to-one correspondence in the specimens to be compared) (Viscosi \& Cardini 2011), should result in a good coverage of the studied morphology, should be observed repeatedly and reliably, and should present coplanarity. The form of the structure is captured using the Cartesian coordinates of a configuration of landmarks. According to Rohlf \& Bookstein (1990: 220221), there are three categories of landmarks (but see Valeri et al. (1998) and Gunz et al. (2005) among other authors for other different types of landmarks). Type 1 landmarks are “discrete juxtapositions of tissue types”. This kind of landmark is preferred because there is 
no need to mention any structures far from the landmark itself. Type 2 landmarks are considered more problematic, because they are identified as "maxima of curvature or other local morphogenetic processes". In archaeology, the majority of the landmarks are Type 2. Type 3 landmarks are described as "extremal points", which renders their use very problematic, mainly because they are taken as endpoints of "as farthest" from other points. The importance of distinguishing the type of landmarks rests not only in the intrinsic quality of each type (Type 1 should be easier to be observed in a repeatedly and reliable way), but also in the amount of information that can be retrieved from each type. Because Type 1 landmarks are located in the middle of different structures, it is possible to identify the directions of forces acting upon that area. The same information cannot be obtained from the analysis of Type 2 landmarks, because they are not completely surrounded by structures (Zeldich et al. 2004: 31).

\subsection{Geometric morphometrics applied to the analysed sample}

In this article, we explore some of the potential applications of GMM in the analysis of the morphology of bifacial points. Five Type 2 landmarks were distributed in order to include the different parts of a bifacial point (Figure 2). The five landmarks satisfactorily cover half of the specimens, which is a frequently used way to reduce the time of data collection in symmetric structures (Viscosi \& Cardini 2011). These five landmarks were digitized in standardized taken photographs using the software TPSDig2 (Rohlf 2015). The photographs were taken with the camera parallel to the projectile point surface. Points were laid flat with their distal ends facing to the right and a metric scale was also included. Virtually flat things like bifacial points can be reasonably analysed using a two-dimensional approach without losing much important information (Velhagen \& Roth 1997; Buchanan \& Collard 2010). The sample included 658 bifacial points from São Paulo, Paraná, Santa Catarina, and Rio Grande do Sul. Photographs were taken from complete and finalized bifacial points, meaning that broken points and preforms were not included in the study. The description of each group is presented in Table 2 and Figure 3 shows the geographic location of groups. Landmarks were later transformed into shape coordinates using Procrustes method. Geometric morphometric analyses were carried out using TPSRegr, TPSSmall, TPSRelw and TPSPLS (Rohlf 2015). For a detailed description of GMM principles, see Okumura \& Araujo (2014).

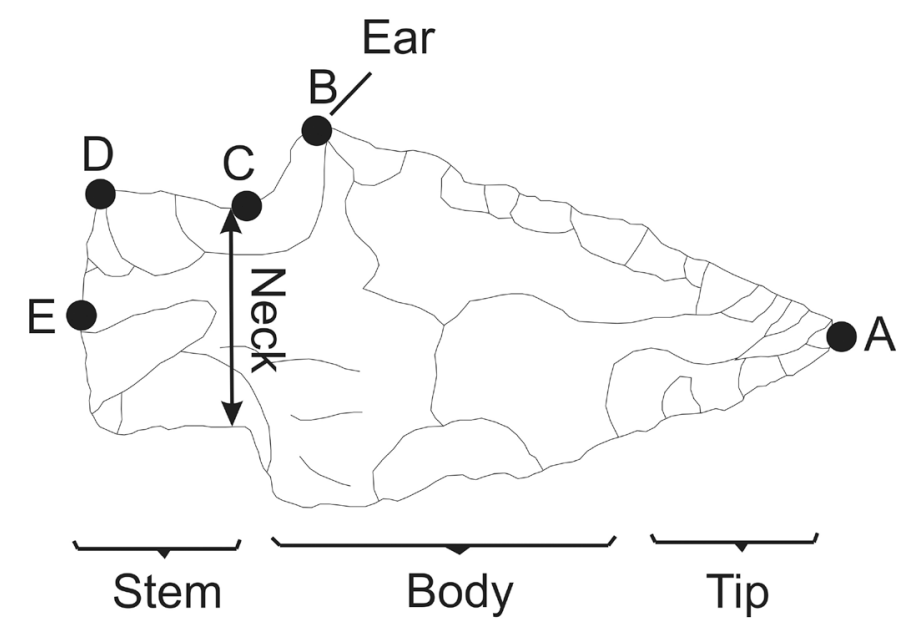

Figure 2: Drawing presenting the different parts of a bifacial point and landmark configuration used to characterize the different parts of a bifacial point. (A) the apex of the body in the longitudinal line (distal end), also defined as the junction of the two blade edges, (B) the most extreme point in the shoulder curve, (C) the point where the neck meets the body, (D) the meeting of the lateral and the basal parts of the stem, and (E) the most extreme point of the stem in the longitudinal line. 


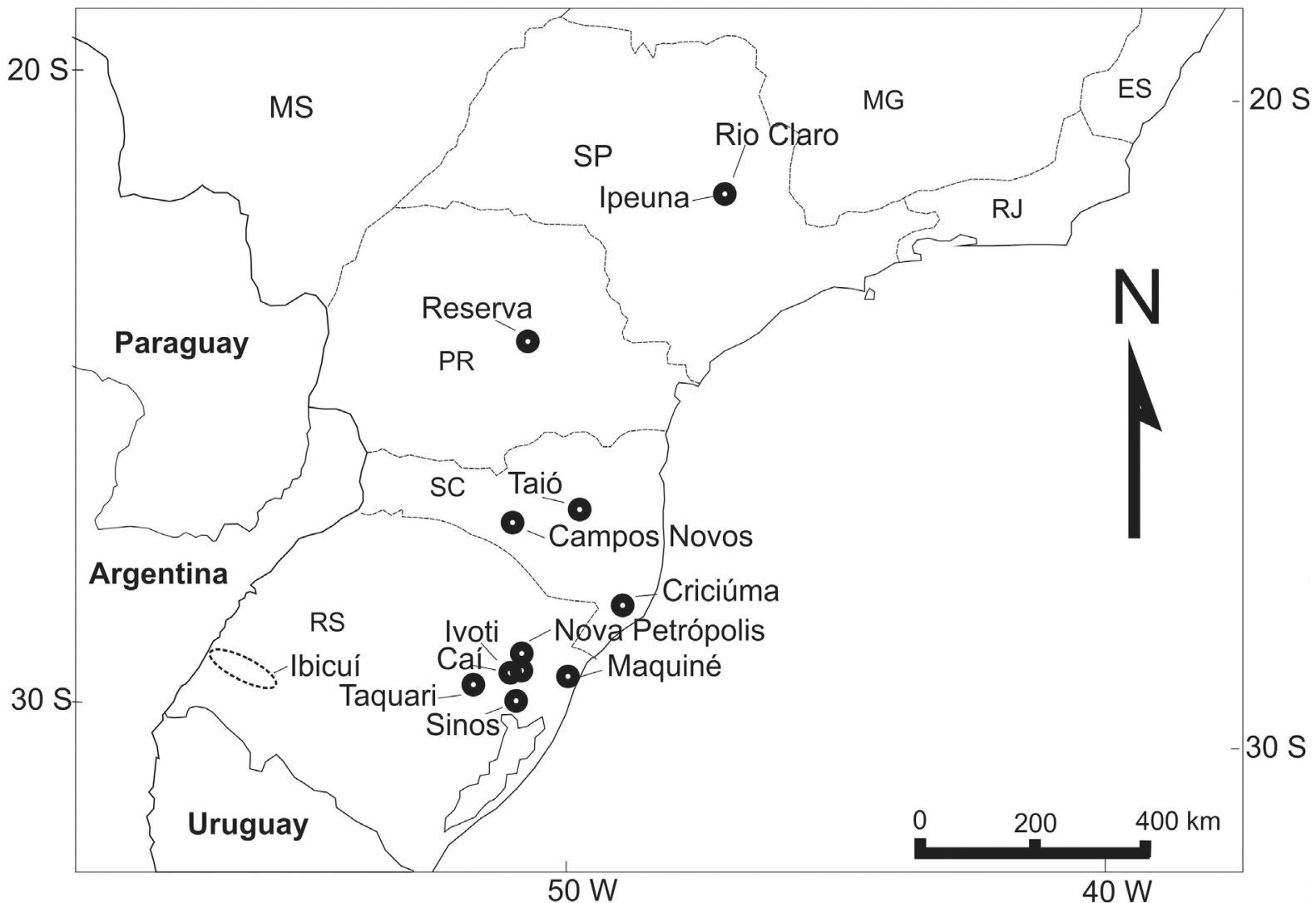

Figure 3: Map presenting the geographic location of the analysed groups.

Table 2: Geographic origin and number of points included in the analysis. Group names in bold refer to groups composed exclusively of points of a single archaeological site, in this case, it was decided to name the group according to the name of the archaeological site.

\begin{tabular}{llclc}
\hline State & Group & Abbreviation & Regions & Number \\
\hline São Paulo (SP) & Alice Boer & Ali & Rio Claro & 47 \\
& Ipeúna & Ipê & Ipeúna & 28 \\
\hline Paraná (PR) & Reserva & Res & Reserva & 108 \\
\hline S. Catarina (SC) & Taió & Tai & Taió & 43 \\
& Criciúma & Cri & Criciúma & 35 \\
& Campos Novos & Cpo & Campos Novos & 9 \\
\hline Rio Grande do Sul (RS) & Caí & Cai & Caí & 35 \\
& Capivara & Cap & Ivoti & 99 \\
& Dalpiaz & Dal & Maquine & 75 \\
& Garivaldino & Gar & Taquari & 101 \\
& Ibicuí & Ibi & Ibicuí & 15 \\
& N. Petrópolis & Npe & N. Petrópolis & 9 \\
& Sinos & Sin & Sinos & 17 \\
& Toca Grande & Toc & Sinos & 37 \\
\hline Total & & & & 658 \\
\hline
\end{tabular}

\section{Results}

In GMM, the centroid size measures the dispersion of landmarks around the centroid of the configuration. Centroid size is a measure of size that is mathematically independent of shape (Zeldich et al. 2004: 13) and it was computed using the five landmarks described in the 
Materials and Methods section. An ANOVA indicated significant differences among groups (F $=10,081$ ). A post hoc Bonferroni test (Table 3) shows that the two groups of São Paulo (Alice Boer and Ipeúna) are similar to each other and significantly different from the others, with the exception of Campos Novos (SC), Ibicuí (RS), and Taió (SC). Figure 4 shows that points from São Paulo are, in general, bigger than those from the south.

Table 3: Results from Bonferroni post hoc test for centroid size. $*=\mathrm{p} \leq 0.05, * *=\mathrm{p} \leq 0.01, * * *=\mathrm{p} \leq 0.001$, ns $=$ not significant.

\begin{tabular}{l|ccccccccccccc} 
& Ali & Ipe & Res & Tai & Cri & Cpo & Cai & Cap & Dal & Gar & Ibi & Npe & Sin \\
& (SP) & (SP) & (PR) & (SC) & (SC) & (SC) & (RS) & (RS) & (RS) & (RS) & (RS) & (RS) & (RS) \\
\hline Toc & $* * *$ & $* * *$ & $\mathrm{~ns}$ & $* *$ & $\mathrm{~ns}$ & $* * *$ & $\mathrm{~ns}$ & $\mathrm{~ns}$ & $\mathrm{~ns}$ & $\mathrm{~ns}$ & $* *$ & $\mathrm{~ns}$ & $\mathrm{~ns}$ \\
Sin & $* *$ & $\mathrm{~ns}$ & $\mathrm{~ns}$ & $\mathrm{~ns}$ & $\mathrm{~ns}$ & $* *$ & $\mathrm{~ns}$ & $\mathrm{~ns}$ & $\mathrm{~ns}$ & $\mathrm{~ns}$ & $\mathrm{~ns}$ & $\mathrm{~ns}$ & \\
Npe & $* * *$ & $* * *$ & $\mathrm{~ns}$ & $* *$ & $\mathrm{~ns}$ & $* * *$ & $\mathrm{~ns}$ & $\mathrm{~ns}$ & $\mathrm{~ns}$ & $\mathrm{~ns}$ & $* *$ & & \\
Ibi & $\mathrm{ns}$ & $\mathrm{ns}$ & $\mathrm{ns}$ & $\mathrm{ns}$ & $\mathrm{ns}$ & $\mathrm{ns}$ & $\mathrm{ns}$ & $*$ & $\mathrm{~ns}$ & $\mathrm{~ns}$ & & \\
Gar & $* * *$ & $* * *$ & $\mathrm{~ns}$ & $*$ & $\mathrm{~ns}$ & $* * *$ & $\mathrm{~ns}$ & $\mathrm{~ns}$ & $\mathrm{~ns}$ & & & \\
Dal & $* * *$ & $\mathrm{~ns}$ & $\mathrm{~ns}$ & $\mathrm{~ns}$ & $\mathrm{~ns}$ & $*$ & $\mathrm{~ns}$ & $\mathrm{~ns}$ & & & & \\
Cap & $* * *$ & $* * *$ & $\mathrm{~ns}$ & $*$ & $\mathrm{~ns}$ & $* * *$ & $\mathrm{~ns}$ & & & & & \\
Cai & $\mathrm{ns}$ & $\mathrm{ns}$ & $\mathrm{ns}$ & $\mathrm{ns}$ & $\mathrm{ns}$ & $\mathrm{ns}$ & & & & & & \\
Cpo & $\mathrm{ns}$ & $\mathrm{ns}$ & $* *$ & $\mathrm{~ns}$ & $* *$ & & & & & & & \\
Cri & $* * *$ & $*$ & $\mathrm{~ns}$ & $\mathrm{~ns}$ & & & & & & & & \\
Tai & $\mathrm{ns}$ & $\mathrm{ns}$ & $\mathrm{ns}$ & & & & & & & & & \\
Res & $* * *$ & $*$ & & & & & & & & & & \\
Ipe & $\mathrm{ns}$ & & & & & & & & & & &
\end{tabular}

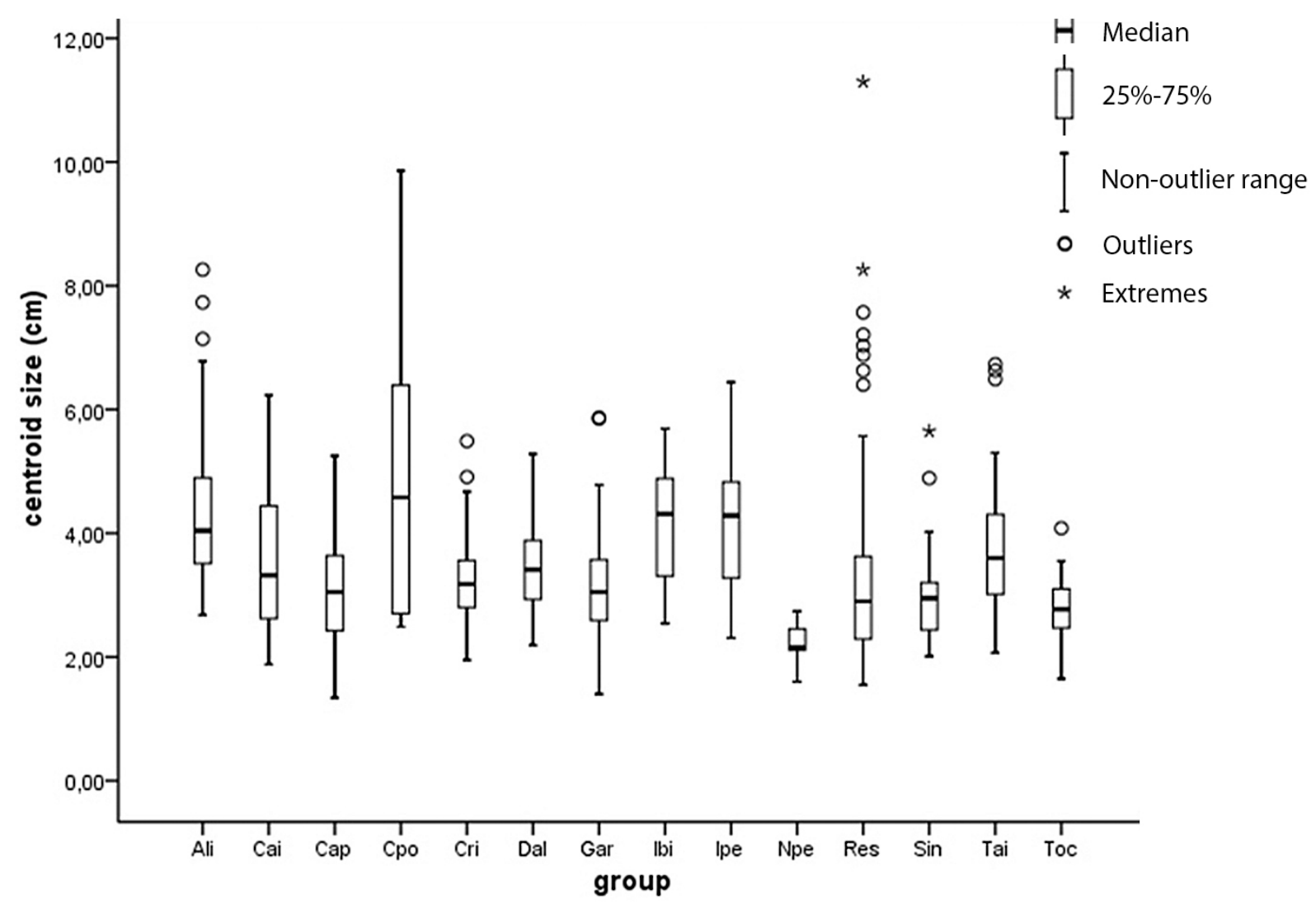

Figure 4: Box-plot graphs based on centroid size. 
Figure 5 presents the Principal Component Analysis applied to the shape coordinates. There is a considerable overlap among the groups. In this case, the consensus shape presented in the upper corner would be located in the center of the chart (coordinates 0,0$)$. It is possible to verify that there are points whose body is long and stem is tapered (points from the upper portion of the graph); points whose body is short and the stem is tapered (points from the right side of the graph); points whose body is short and the stem is forked (lower portion of the graph); and points whose body is long and the stem is forked (left portion of the graph). A higher frequency of short bodies observed in some samples possibly indicates episodes of resharpening. The importance of resharpening, which relates to an allometric relation between shape and size is also indicated through the high correlation observed between the aligned data and centroid size (0.50721).

From the Relative Warps Score Matrix, we performed a Canonical Analysis using the entire matrix. The graph representing the two functions of this canonical analysis (Figure 6) shows that the two groups of São Paulo present a different shape compared to the southern groups. It is also possible to verify an association between Paraná and Santa Catarina, especially Reserva (PR) and Taió (SC). The morphological similarity between points from these two regions was also observed in the analysis of linear measurements (Okumura \& Araujo 2015b).

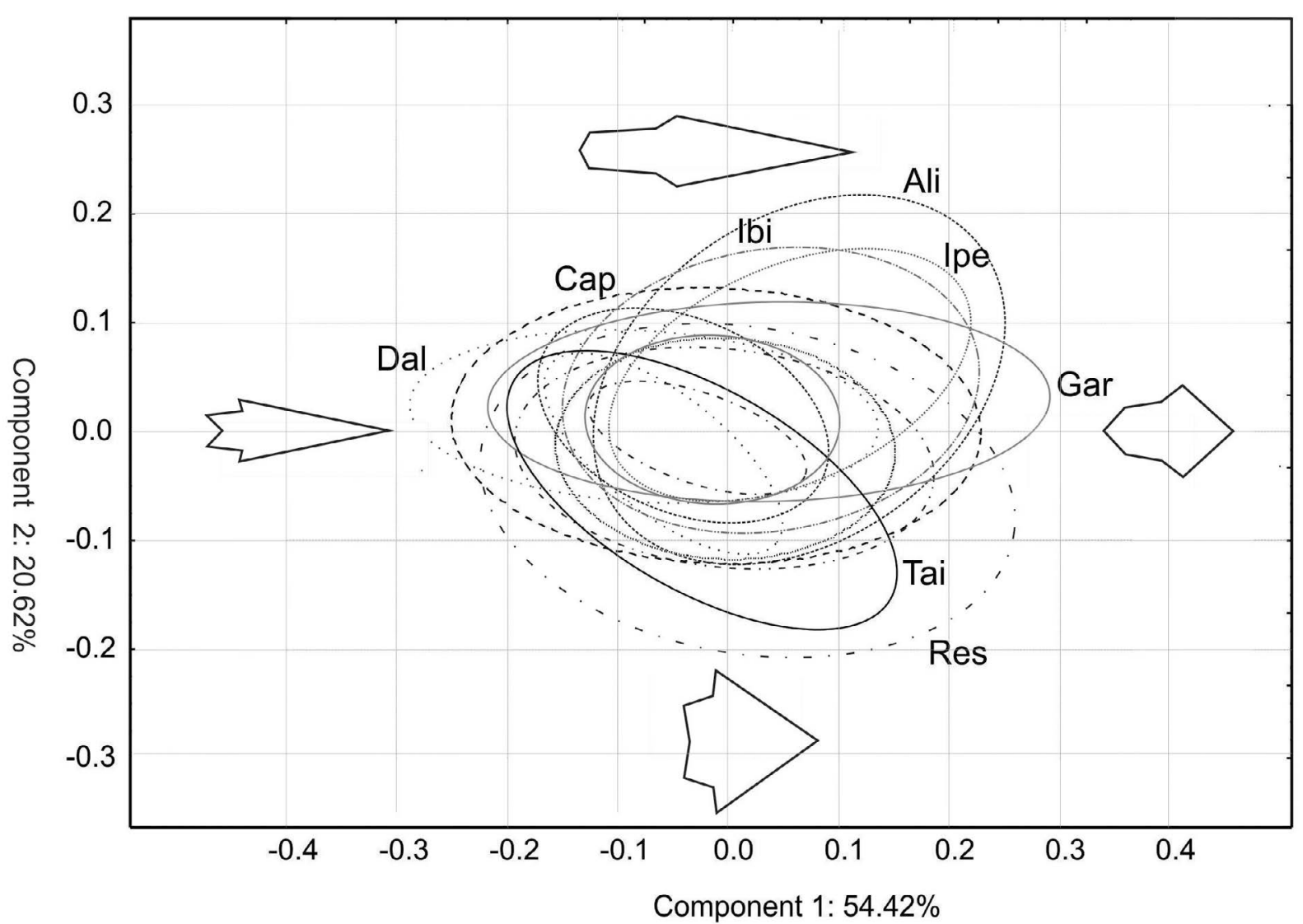

Figure 5: Principal Component Analysis applied to the shape coordinates. Upper corner: consensus shape (note that the program output represents half of the point). 


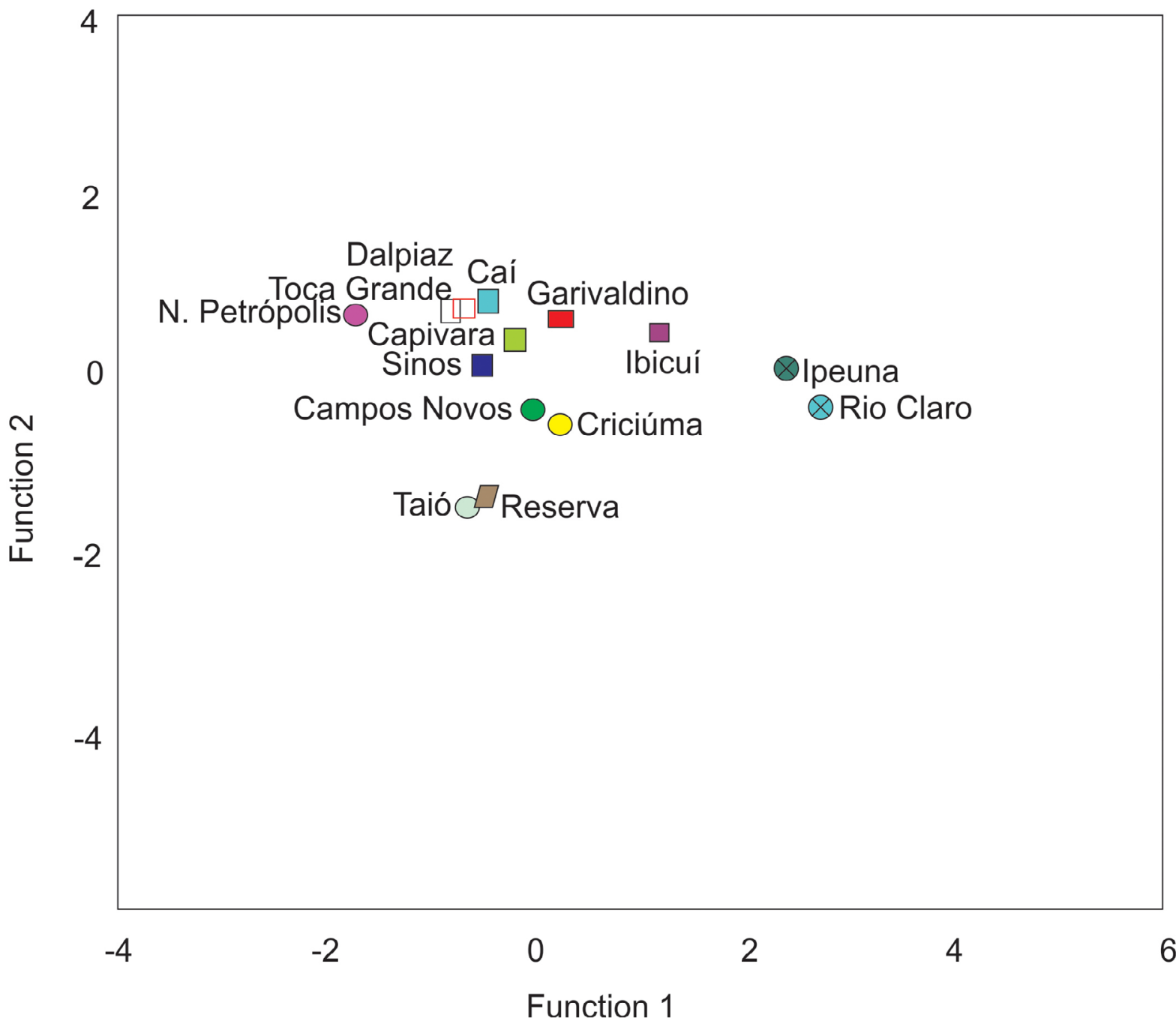

Figure 6: Graph representing the two canonical functions. Crossed circles: São Paulo state, parallelogram: Paraná state, circles: Santa Catarina state, and squares: Rio Grande do Sul state. The first function explains $53,4 \%$ of total variance and the second function explains $35,5 \%$.

\section{Discussion and conclusions}

The GMM analysis point to the presence of significant differences in the size and shape of the bifacial points from São Paulo compared to the southern region. The bifacial points from the two groups from São Paulo (Rio Claro and Ipeúna) presented high morphological similarity. In general, the bifacial points from São Paulo seem to be larger than the other groups (with the exception of two groups from the south: Campos Novos and Ibicuí). Such results have been previously observed through the analysis of linear measurements of points from Rio Claro and southern states (Okumura \& Araujo 2015b). Although we believe it is not necessary to revive the category "Rio Claro tradition", our preliminary results point to an important difference in the morphology of the points from São Paulo in relation to the southern points of the country. Since Umbu tradition was defined based on the material found in southern sites, the points from São Paulo could not be considered part of this group. It may be possible that the points from Minas Gerais and Mato Grosso do Sul are also distinct from the points of the southern region.

There is evidence of similarity between the points from Paraná and Santa Catarina, as well as between some groups in Rio Grande do Sul (Okumura \& Araujo 2013; 2015b). Such similarities could be exacerbated due to the huge difference between the points from São 
Paulo and the rest of the sample, which makes southern Brazil materials appear more homogeneous (Okumura \& Araujo 2015b). Further analysis, considering only southern Brazil will aim to explore the diversity within this region.

Our data shows, therefore, a very intriguing pattern, where differences in point morphology seem to reflect territorial and probably identity group differences between southern and southeastern hunter-gatherer groups in Brazil. These differences were not formerly recognized, due to the lack of both an explicit comparison between points of different regions, and of statistically based studies as well. Far from being definitive, our data can be considered an initial effort in approaching this diversity, and could be used as a guide for future research, that should involve the study of more specific themes related to bifacial points, including raw material types, resharpening and artifact life histories, as well as the analysis of other categories of artifacts, the technology behind the point manufacture, and subsistence issues.

\section{Acknowledgements}

We would like to thank the colleagues of the institutions that house the collections studied by us: Adriana Schmidt Dias (UFRGS); Dione da Rocha Bandeira and Adriana Maria Pereira dos Santos (MASJ); Jefferson Dias (Marsul); Marisa Coutinho Afonso, Dária Barreto and Paulo Jacob (MAE-USP); Juliano Bitencourt Campos (Unesc), Natália Zanella (Museu Universitário-PUC Campinas), Pedro Ignácio Schmitz (IAP-Unisinos); Sérgio Klamt (CEPAUNISC); Teresa Fossari (Museu Universitário Professor Oswaldo Rodrigues Cabral-UFSC), and private collectors. This research was supported by grants from CNPq (159776/2010-4, 303566/2014-0, 443169/2014-9) and FAPESP (09/54720-9; 2010/06453-9).

\section{References}

Araujo, A.G.M. 2012, A Ocupação Paleoíndia no Estado de São Paulo: Uma Abordagem Geoarqueológica. Final report, FAPESP, 2010-2012. MAE-USP, São Paulo. (in Portuguese) ("The Paleoindian occupation in São Paulo: A Geoarchaeological Approach”)

Archer, W. \& Braun, D.R. 2010, Variability in bifacial technology at Elandsfontein, Western cape, South Africa: A geometric morphometric approach. Journal of Archaeological Science, 37(1): 201-209. doi:10.1016/j.jas.2009.09.033

de Azevedo, S., Charlin, J. \& González-José, R. 2013, Identifying design and reduction effects on lithic projectile point shapes. Journal of Archaeological Science, 41: 297-307 doi:10.1016/j.jas.2013.08.013

Binford, L.R. 1977, Forty-seven trips: A case study in the character of archaeological formation process. In: Stone tools as cultural markers: Change, evolution, and complexity (Wright, R.V.S., Ed.), Australian Institute of Aboriginal Studies, Canberra: p. 24-36.

Binford, L.R. 1979, Organizational and formation processes: Looking at curated technologies. Journal of Anthropological Research, 35: 255-273.

Stable URL: http://www.jstor.org/stable/3629902

de Blasis, P.A.D. 1996, Bairro da Serra em três tempos. Arqueologia, uso do espaço regional e continuidade cultural no médio vale do Ribeira PhD thesis at the FFLCH, Universidade de São Paulo, São Paulo, 166 p. (in Portuguese) ("Serra neighborhood in 
three stages. Archaeology, use of regional space and cultural continuity in the middle valley of the Ribeira river")

Bookstein, F.L. 1991, Morphometric Tools for Landmark Data: Geometry and Biology. Cambridge University Press, Cambridge. 435 p.

Bordes, F. 1950, Principes d'une méthode d'étude des techniques de débitage et de la typologie du Paléolithique ancien et moyen. L'Anthropologie, 54: 19-34. (in French) ("Principles of a method of studying knapping techniques and the typology of Early and Middle Palaeolithic")

Brochado, J.P. \& Schmitz, P.I. 1973, Aleros y cuevas com petroglifos e industria lítica de la escarpa del Planalto Meridional en Rio Grande do Sul, Brasil. Anales de Arqueologia y Etnologia (Mendoza), 27-28(1972-1973): 39-66. (in Spanish) ("Rockshelters presenting petrogliphs and lithic industry from the escarpment of the Southern Plateau in Rio Grande do Sul, Brazil”)

Brown, K.S., Marean, C.W., Jacobs, Z., Schoville, B.J., Oestmo, S., Fisher, E.C., Bernatchez, J., Karkanas, P. \& Matthews, T. 2012, An early and enduring advanced technology originating 71,000 years ago in South Africa. Nature, 491(7425): 590-593. doi:10.1038/nature11660

Buchanan, B. \& Collard, M. 2010, A geometric morphometrics-based assessment of blade shape differences among Paleoindian projectile point types from western North America. Journal of Archaeological Science, 37: 350-359. doi:10.1016/j.jas.2009.09.047

Buchanan, B., Johnson, E., Strauss, R.E. \& Lewis, P.J. 2007, A morphometric approach to assessing Late Paleoindian projectile point variability. Plains Anthropologist, 52(203): 279-299. doi:10.1179/pan.2007.019

Caldarelli, S.B. 1983, Lições de pedra: Aspectos da ocupação pré-histórica no Vale Médio do Rio Tietê. PhD thesis at the FFLCH, Universidade de São Paulo, São Paulo, 355 p. (in Portuguese) ("Stone Lessons: aspects of prehistoric occupation in the Middle Valley of Tiete River”)

Cardillo, M. 2006, Explorando la variación en las morfologías líticas a partir de las técnicas de análisis de contornos. El caso de las puntas de proyectil del holoceno medio-tardío de la Puna de Salta (San Antonio de los Cobres, Argentina). Werken, 7: 77-88. (in Spanish) ("Exploring the variation in lithic morphology using the technique of contours analysis. The case of projectile points from mid-late Holocene Puna de Salta (San Antonio de los Cobres, Argentina) URL: http://www.redalyc.org/pdf/508/50800705.pdf

Cardillo, M. 2009, Variabilidad en la manufactura y diseño de artefactos en el área costera patagónica. Un enfoque integrador. PhD thesis at the Facultad de Filosofía y Letras, Universidad de Buenos Aires, Buenos Aires. 489 p. (in Spanish) ("The variability in manufacturing and designing artifacts in the Patagonian coastal area. An integrated approach)

Cardillo, M. 2010, Some Applications of Geometric Morphometrics to Archaeology. In: Morphometrics to Nonmorphometricians (Elewa, A.M.T., Ed.) Lecture Notes in Earth Sciences Vol. 124, Springer, Berlin: p. 325-341. doi:10.1007/978-3-540-95853-6_15

Cardillo, M., Borrazzo, K. \& Charlin, J. (in press), Environment, space, and morphological variation of projectile points in Patagonia (Southern South America). Quaternary International. doi:10.1016/j.quaint.2015.11.134 
Castiñeira, C., Cardillo, M., Charlin, J., Fernicola, J.C. \& Baeza, J. 2009, Análisis morfométrico de cabezales líticos “cola de pescado” de la Rep. Oriental del Uruguay. In: Actas del Segundo Congreso Argentino de Arqueometría y Primero Latinoamericano Vol. 2 (Palacios, O.M., Vázquez, C., Palacios, T. \& Cabanillas, E., Eds.), Comisión Nacional de Energía Atómica/Centro Atómico Constituyentes, Buenos Aires: p. 360-366. (in Spanish) ("Morphometric analysis of "fishtail” lithic points from the Oriental Republic of Uruguay")

Castiñeira, C., Cardillo, M., Chalin, J. \& Baeza, J. 2011, Análisis de morfometría geométrica en puntas Cola de Pescado del Uruguay. Latin American Antiquity, 22(3): 335-358. (in Spanish) ("Geometric morphometric analysis in Fishtail points from Uruguay") doi:10.7183/1045-6635.22.3.335

Castiñeira, C., Charlin, J., Cardillo, M. \& Baeza, J. 2012, Exploring Morphometric Variations in Fishtail Projectile Points from Uruguay, Pampa, and Patagonia. In: Southbound: Late Pleistocene Peopling of Latin America (Miotti, L., Salemme, M., Flegenheimer, N. \& Goebel, T., Ed.), Center for the Study of the First Americans, Department of Anthropology, Texas A\&M University, College Station, Texas: p. 9-13.

Cattelain, P. 1997, Hunting during the Upper Paleolithic: Bow, spearthrower, or both? In: Projectile Technology (Knecht, H., Ed.), Plenum, New York: p. 213-240.

Charlin, J. \& González-José, R. 2012, Size and Shape Variation in Late Holocene Projectile Points of Southern Patagonia: A Geometric Morphometric Study. American Antiquity, 77(2): 221-242. Stable URL: http://www.jstor.org/stable/23486059

Charlin, J., Cardillo, M. \& Borrazzo, K. 2014, Spatial patterns in Late Holocene lithic projectile point technology of Tierra del Fuego (southern South America): Assessing size and shape changes. World Archaeology, 46(1): 78-100. doi:10.1080/00438243.2014.890914

Chmyz, I. 1969, Comentários sobre as Culturas Pré-Cerâmicas no Estado do Paraná. Pesquisas (Antropologia) Anais do Terceiro Simpósio de Arqueologia da Área da Prata, 20: 13-24. (in Portuguese) ("Comments on the Pre-Pottery Culture in the State of Paraná”)

Chmyz, I. 1977, Pesquisas paleoetnográficas efetuadas no vale do rio Paranapanema, Paraná São Paulo. Boletim de Psicologia e Antropologia, 5: 1-248. (in Portuguese) ("Paleoetnographic surveys conducted in the valley of the Paranapanema river, Paraná Sao Paulo")

Chmyz, I. 1981a, Relatório arqueológico das pesquisas realizadas na área da Usina Hidrelétrica de Salto Santiago (1979-80). Convênio Eletrosul, Iphan, Projeto Arqueológico Santiago. Commercial archaeology report, for IPHAN (Instituto do Patrimônio Histórico e Artístico Nacional - Brazilian Department of Antiquities), Florianópolis e Curitiba. 101 p. (in Portuguese) (“Archaeological report of research conducted in the area of hydroelectric power plant Salto Santiago (1979-80). Eletrosul, Iphan, Archaeological Project Santiago”)

Chmyz, I. 1981b, Relatório das pesquisas arqueológicas realizadas na área da Usina Hidrelétrica Foz do Areia. Commercial archaeology report, for IPHAN, Convênio COPEL - UFPR, Curitiba. 127 p. (in Portuguese) ("Report on archaeological research conducted in the area of Power Plant Foz do Areia”) 
Chmyz, I. 1983, Sétimo Relatório das Pesquisas Realizadas na Área de Itaipu. Commercial archaeology report, for IPHAN, Projeto Arqueológico Itaipu. Convênio Itaipu-IPHAN, Curitiba. 106 p. (in Portuguese) ("Seventh Report of the Research Performed in Itaipu Area”)

Chmyz, I. \& Chmyz, J.C.G. 1986, Datações radiométricas em áreas de salvamento arqueológico no Estado do Paraná. Arqueologia (Revista do CEPA), 5: 69-78. (in Portuguese) ("Radiometric dating in archaeological rescue areas in the State of Paraná")

Chmyz, I. \& PRONAPA (Eds.) 1976, Terminologia arqueológica brasileira para a cerâmica segunda edição revista e ampliada. Cadernos de Arqueologia (UFPR), 1: 119-148. (in Portuguese) ("Brazilian archaeological terminology for ceramics - revised and expanded second edition”)

Chmyz, I., Sganzerla, E.M., Volcov, J.E., Bora, E. \& Ceccon, R.S. 2008, A arqueologia da área da LT 750kV Ivaiporã-Itaberá III, Paraná - São Paulo. Arqueologia (Revista do CEPA), 5(Número Especial): 1-305. (in Portuguese) ("The archaeology of the area LT 750kV Ivaiporã - Itaberá III, Paraná - Sao Paulo”)

Collet, G.C. 1985, Novas informações sobre os sambaquis fluviais do Estado de São Paulo. Arquivos do Museu de História Natural, 10: 311-324. (in Portuguese) ("New information on the riverine shellmounds from the State of São Paulo")

Costa, A.G. 2010, A geometric morphometric assessment of plan shape in bone and stone Acheulean bifaces from the Middle Pleistocene site of Castel di Guido, Latium, Italy. In: New Perspectives on Old Stones: Analytical Approaches to Paleolithic Technologies (Lycett, S.J. \& Chauhan, P.R., Eds.), Springer, New York: p. 23-41.

Davis, L.G., Bean, D.W., Nyers, A.J. \& Brauner, D.R. 2015, GLiMR: A GIS-based method for the geometric morphometric analysis of artifacts. Lithic Technology, 40(3): 199-217. doi:10.1179/2051618515Y.0000000007

Dias, A.S. 2003, Sistemas de assentamento e estilo tecnológico: Uma proposta interpretativa para a ocupação pré-colonial do alto Vale do Rio dos Sinos, Rio Grande do Sul. $\mathrm{PhD}$ thesis at the FFLCH, Universidade de São Paulo, São Paulo, 326 p. (in Portuguese) ("Settlement systems and technological style: An interpretive proposal for the precolonial occupation of Sinos River Valley, Rio Grande do Sul”)

Dias, A.S. 2007, Novas perguntas para um velho problema: Escolhas tecnológicas como índices para o estudo de fronteiras e identidades sociais no registro arqueológico. Boletim do Museu Paraense Emílio Goeldi (Ciências Humanas), 2(1): 59-76. (in Portuguese) ("New questions for an old problem: Technological choices as indexes for the study of borders and social identities in the archaeological record")

Dias, A.S. 2012, Hunter-gatherer occupation of south Brazilian Atlantic Forest: Paleoenvironment and archaeology. Quaternary International, 256: 12-18. doi:10.1016/j.quaint.2011.08.024

Dias, A.S. \& Hoeltz, S.E. 2010, Indústrias líticas em contexto: O problema Humaitá na arqueologia sul brasileira. Revista de Arqueologia, 23: 40-67. (in Portuguese) ("Lithic industries in context: The Humaita problem in southern Brazilian archaeology")

Dias, A.S. \& Jacobus, A.L. 2003, Quão antigo é o povoamento do Sul do Brasil? Revista do CEPA (Santa Cruz do Sul), 27(38): 39-67. (in Portuguese) ("How old is the peopling of southern Brazil?”) 
Dias, A.S. \& Neubauer, F. 2010, Um estudo contextual da indústria lítica do sítio RS-C-61: Adelar Pilger (Rio Grande do Sul, Brasil). Cazadores-recolectores del Cono Sur. Revista de Arqueología, 4: 187-206. (in Portuguese) (“A contextual study of the lithic industry from site RS-C-61: Adelar Pilger (Rio Grande do Sul, Brazil)”)

Documento Ltda. 2003, Programa de Resgate Arqueológico do Contorno Rodoviário de Moji-Mirim/SP. Final report. Commercial archaeology report, for IPHAN, São Paulo. (in Portuguese) ("Program of archaeological rescue in the road Moji-Mirim / SP")

Draper, N. 1985, Back to the drawing board: A simplified approach to assemblage variability in the Early Palaeolithic. World Archaeology, 17(1): 3-19. doi:10.1080/00438243.1985.9979946

Dunnell, R.C. 1971, Systematics in Prehistory. The Free Press, New York. 214 p.

Dunnell, R.C. 1978, Style and function: A fundamental dichotomy. American Antiquity, 43: 192-202. doi:10.2307/279244

Erlandson, J., Watts, J.L. \& Jew, N.P. 2014, Darts, arrows, and archaeologists: Distinguishing dart and arrow points in the archaeological record. American Antiquity, 79: 162-169. doi:10.7183/0002-7316.79.1.162

Fenenga, F. 1953, The weights of chipped stone points: A clue to their functions. Southwestern Journal of Anthropology, 9(3): 309-323.

Stable URL: http://www.jstor.org/stable/3628702

Fox, A.N. 2015, A study of Late Woodland projectile point typology in New York using elliptical Fourier outline analysis. Journal of Archaeological Science: Reports, 4: 501509. doi:10.1016/j.jasrep.2015.10.022

Franco, N.V., Castro, A., Cardillo, M. \& Charlin, J. 2009, La importancia de las variables morfológicas, métricas y de microdesgaste para evaluar las diferencias en diseños de puntas de proyectil bifaciales pedunculadas: Un ejemplo del Sur de Patagonia continental. Magallania (Chile), 37(1): 99-112. (in Spanish) ("The importance of the morphological and metric varibleas, and microwear to evaluate differences in the design of stemmed bifacial projectile points: An example of Southern Patagonia continental”) doi:10.4067/S0718-22442009000100008

Greaves, R.D. 1997, Hunting and multifunctional use of bows and arrows: Ethnoarchaeology of technological organization among Pumé hunters of Venezuela. In: Projectile technology (Knecht, H., Ed.), Plenum, New York: p. 287-320.

Gunz, P., Mitteroecker, P. \& Bookstein, F.L. 2005, Semilandmarks in three dimensions. In: Modern morphometrics in physical anthropology (Slice, D.E., Ed.), Springer US, New York: p. 73-98.

Hilbert, K. 1991, Aspectos de la arqueología en el Uruguay. Materialien zur allgemeinen und vergleichenden Archäologie Vol. 44. Verlag Philipp von Zabern, Mainz am Rhein, 189 p. (in Spanish) ("Aspects of Archaeology in Uruguay")

Hilbert, K. 1994, Caçadores coletores pré-históricos no sul do Brasil: Um projeto para a redefinição das tradições líticas Umbu e Humaitá. In: Negros e índios: Literatura e história (Flores, M., Ed.) Coleção História (Porto Alegre, Rio Grande do Sul, Brazil) Vol. 2, EdiPUCRS, Porto Alegre: p. 9-24. (in Portuguese) ("Prehistoric hunter-gatherers in southern Brazil: A project for the redefinition of lithic traditions Umbu and Humaita") 
Iovita, R. 2011, Shape variation in Aterian tanged tools and the origins of projectile technology: A morphometric perspective on stone tool function. PloS one, 6(12): e29029. doi:10.1371/journal.pone.0029029

Juliani, L.J.C.O. 2012, Relatório de campo da terceira fase de resgate arqueológico do sítio Carcará. Report. Programa de Resgate Científico do Patrimônio Cultural Arqueológico - Loteamento Alphaville, São José dos Campos. 141 p. (in Portuguese) ("Field report of the third phase of the archaeological rescue of Carcará site”)

Kashimoto, E.l.M. \& Martins, G.R. 2009, Arqueologia e Paleoambiente do Rio Paraná em Mato Grosso do Sul (1 ed.). Life, Campo Grande, 335 p. (in Portuguese) (“Archaeology and palaeoenvironment of the Parana River in Mato Grosso do Sul”)

Kay, M. 1996, Microwear analysis of some Clovis and experimental chipped stone tools. In: Stone Tools: Theoretical Insights into Human Prehistory (Odell, G., Ed.), Plenum Press, New York: p. 315-344.

Kern, A.A. 1981, Le précéramique du plateau sud-brésilien. $\mathrm{PhD}$ thesis at Ecole des Hautes Études en Sciences Sociales (EHESS), Paris. 427 p. (in French) (“The preceramic culture from southern Brazilian plateau”)

Koole, E.K.M. 2007, Pré-história da província Cárstica do Alto São Francisco, Minas Gerais: A indústria lítica dos caçadores-coletores arcaicos. MPhil dissertation at the Museu de Arqueologia e Etnologia, Universidade de São Paulo, São Paulo, 139 p. (in Portuguese) ("Prehistory of carstic province of Upper São Francisco, Minas Gerais: The lithic industry of archaic hunter-gatherers”)

Koole, E.K.M. 2014, Entre as tradições planálticas e meridionais: Caracterização arqueológica dos grupos caçadores coletores a partir da análise de sete elementos e suas implicações para a ocupação pré-cerâmica da Região Cárstica do Alto São Francisco, Minas Gerais, Brasil: Cronologia, tecnologia lítica, subsistência (fauna), sepultamentos, mobilidade, uso do espaço em abrigos naturais e arte rupestre. $\mathrm{PhD}$ thesis at the Museu de Arqueologia e Etnologia, Universidade de São Paulo, São Paulo. 564 p. (in Portuguese) ("Between the plateau and southern traditions: Archaeological characterization of hunter-gatherers groups analysing seven elements and its implications for the pre-ceramic occupation of the carstic region of the Upper São Francisco, Minas Gerais, Brazil: Chronology, lithic technology, subsistence (faunal remains), burials, mobility, use of space in natural shelters, and rock art”)

Lycett, S.J. \& von Cramon-Taubadel, N. 2008, Acheulean variability and hominin dispersals: A model-bound approach. Journal of Archaeological Science, 35: 553-562. doi:10.1016/j.jas.2007.05.003

Lycett, S.J. \& Eren, M.I. 2013, Levallois economics: An examination of 'waste’production in experimentally produced Levallois reduction sequences. Journal of Archaeological Science, 40(5): 2384-2392. doi:10.1016/j.jas.2013.01.016

Lycett, S.J., von Cramon-Taubadel, N. \& Gowlett, J.A.J. 2010, A comparative 3D geometric morphometric analysis of Victoria West cores: Implications for the origins of Levallois technology. Journal of Archaeological Science, 37(5): 1110-1117. doi:10.1016/j.jas.2009.12.011

Martins, G.R. \& Kashimoto, E.M. 2012, 12.000 anos: Arqueologia do povoamento humano no nordeste de Mato Grosso do Sul. Life, Campo Grande. 190 p. (in Portuguese) (“12,000 years: Archaeology of human settlement in northeastern Mato Grosso do Sul”) 
McKern, W.C. 1939, The Midwestern Taxonomic Method as an aid to archaeological culture study. American Antiquity, 4: 301-313. doi:10.2307/276087

Meggers, B.J. \& Evans, C. 1985, A utilização de sequências cerâmicas seriadas para inferir comportamento social. Instituto de Arqueologia Brasileira (Boletim Série Ensaios), 3: 1-48. (in Portuguese) ("The use of ceramic serial sequences to infer social behaviour")

Milder, S.E.S. 1999, Caçadores coletores: A problemática arqueológica e ambiental sobre os primeiros povoadores do Rio Grande do Sul. Revista do CEPA (Santa Cruz do Sul), 23: 7-56. (in Portuguese) ("Hunter-gatherers: The archaeological and environmental issues on the first settlers of the Rio Grande do Sul”)

Miller, E.T. 1967, Pesquisas arqueológicas efetuadas no Nordeste do Rio Grande do Sul. In: Programa Nacional de Pesquisas Arqueológicas: Resultados preliminares do primeiro ano, 1965-1966 (Simões, M., Ed.) Publicações avulsas (Museu Paraense Emílio Goeldi) Vol. 6, Conselho Nacional de Pesquisas, Instituto nacional de Pesquisas da Amazonia, Museu Paraense Emílio Goeldi, Belem, Pará: p. 15-38. (in Portuguese) ("Archaeological research made in northeastern Rio Grande do Sul")

Miller, E.T. 1974, Pesquisas arqueológicas em abrigos-sob-rocha no Nordeste do Rio Grande do Sul. In: Programa Nacional de Pesquisas Arqueológicas: Resultados Preliminares do Quinto Ano (1969-1970) (Simões, M., Ed., Ed.) Publicações Avulsas do Museu Paranaense Emílio Goeldi Vol. 26, Conselho Nacional de Pesquisas, Instituto nacional de Pesquisas da Amazonia, Museu Paraense Emílio Goeldi, Belem, Pará: p. 11-24. (in Portuguese) ("Archaeological research in rockshelters in northeast Rio Grande do Sul")

Miller, E.T. 1987, Pesquisas arqueológicas paleoindígenas no Brasil Ocidental. Estudios Atacameños, 8: 37-61. (in Portuguese) ("Paleoindigenous archaeological research in Western Brazil”)

Miller Jr., T.O. 1972, Arqueologia da região central do Estado de São Paulo. Dédalo, 16: 13118. (in Portuguese) (“Archaeology of the central region of São Paulo”)

Neves, W.A., Hubbe, M., Okumura, M.M.M., González-José, R., Figuti, L., Eggers, S. \& DeBlasis, P.A.D. 2005, A new early Holocene human skeleton from Brazil: Implications for the settlement of the New World. Journal of Human Evolution, 48(4): 403-414. doi:10.1016/j.jhevol.2004.12.001

Noelli, F.S. 2000, A ocupação humana na região sul do Brasil: Arqueologia, debates e perspectivas. Revista USP, 44(1999-2000): 218-269. (in Portuguese) (“The human occupation in southern Brazil: Archaeology, debates and perspectives”)

Okumura, M. 2015, Dardo ou flecha? Testes e reflexões sobre a tecnologia de uso de pontas de projétil no Sudeste e Sul do Brasil durante a pré-história. Cadernos do LEPAARQ, 12(24): 8-32. (in Portuguese) ("Dart or arrow? Tests and reflections on the use of projectile points in Southeast and Southern Brazil during prehistory")

Okumura, M. \& Araujo, A.G.M. 2013, Pontas bifaciais no Brasil Meridional: Caracterização estatística das formas e suas implicações culturais. Revista do Museu de Arqueologia e Etnologia, 23: 111-127. (in Portuguese) ("Bifacial points from Southern Brazil: Statistical characterization of forms and its cultural implications”)

Okumura, M. \& Araujo, A.G.M. 2014, Long-term cultural stability in hunter-gatherers: A case study using traditional and geometric morphometric analysis of lithic stemmed bifacial points from Southern Brazil. Journal of Archaeological Science, 45: 59-71. doi:10.1016/j.jas.2014.02.009 
Okumura, M. \& Araujo, A.G.M. 2015a, Contributions to the dart versus arrow debate: New data from Holocene projectile points from Southeastern and Southern Brazil. Anais da Academia Brasileira de Ciências, 87(4): 2349-2373. doi:10.1590/0001-3765201520140625

Okumura, M. \& Araujo, A.G.M. 2015b, Desconstruindo o que nunca foi construído: Pontas bifaciais 'Umbu' do Sul e Sudeste do Brasil. Revista do Museu de Arqueologia e Etnologia, Suplemento 20: 77-82. (in Portuguese) ("Deconstructing what was never built: 'Umbu” bifacial points from Southern and Southeastern Brazil”)

Pallestrini, L. \& Chiara, P. 1978, Indústria lítica de Camargo 76 Município de Pirajú - Estado de São Paulo. Coleção do Museu Paulista, Série Ensaios. Coletânea em Homenagem a Annette Laming-Emperaire, 2: 91-122. (in Portuguese) ("Lithic industry of Camargo 76 site, Municipality of Pirajú - São Paulo state”)

Parellada, C.I. 1999, Programa de salvamento arqueológico da Usina Hidrelétrica de Salto Caxias/PR. In: XV Seminário Nacional de Produção e Transmissão de Energia Elétrica. ITAIPU Binacional, Foz do Iguaçu. 6 p. (in Portuguese) (“Archaeological rescue program of power plant Salto Caxias / PR”)

Parellada, C.I. 2005, Estudo arqueológico no alto vale do rio Ribeira: Área do Gasoduto Bolívia-Brasil, trecho X, Paraná. PhD thesis at the Museu de Arqueologia e Etnologia, Universidade de São Paulo, São Paulo, 262 p. (in Portuguese) (“Archaeological study in the Upper valley of the Ribeira river: Area of the Bolivia -Brazil gas pipeline, Paraná”)

Perlés, C. 1992, In search of lithic strategies: A cognitive approach to prehistoric chipped stone assemblages. In: Representations in Archaeology (Peebles, C. \& Gardin, J.-C., Eds.), Indiana University Press, Bloomington: p. 223-247.

Phillips, P. \& Willey, G.R, 1953, Method and theory in American Archaeology: An operational basis for culture-historical integration. American Anthropologist, 55: 615633. doi:10.1525/aa.1953.55.5.02a00030

Piazza, W. 1974, Dados à arqueologia do Litoral Norte e do Planalto de Canoinhas. In: Programa Nacional de Pesquisas Arqueológicas: Resultados Preliminares do Quinto Ano (1969-1970) (Simões, M., Ed.) Publicações Avulsas do Museu Paranaense Emílio Goeldi Vol. 26, Conselho Nacional de Pesquisas, Instituto nacional de Pesquisas da Amazonia, Museu Paraense Emílio Goeldi, Belem, Pará: p. 53-68. (in Portuguese) ("Data to the archaeology of the North Coast and the Canoinhas Plateau")

Pitt Rivers, A.H.L.-F. 1906, The Evolution of Culture and Other Essays. Clarendon Press, Oxford. 232 p. URL: http://archive.org/stream/evolutioncultur01pittgoog

Plens, C.R. 2007, Sítio Moraes, uma biografia não autorizada: Análise do processo de formação de um sambaqui fluvial. PhD thesis at the Museu de Arqueologia e Etnologia, Universidade de São Paulo, São Paulo. 240 p. (in Portuguese) (“Site Moraes, an unauthorized biography: Analysis of the formation process of a riverine shell mound")

Politis, G. 2008, The pampas and campos of South America. In: The Handbook of South American Archaeology (Silverman, H. \& Isbell, W.H., Eds.), Springer, New York: p. 235-260.

Prous, A. 1991, Arqueologia brasileira. Universidade de Brasília, Brasília. 605 p. (in Portuguese) ("Brazilian archaeology”) 
Rausing, G. 1967, The bow: Some notes on its origin and development. Acta archaeologica Lundensia (Papers of the Lunds Universitets Historiska Museum), Series in 80, nr. 6. Rudolf Habelt Verlag / CWK Gleerups Förlag, Bonn A. R. / Lund, 189 p.

Ribeiro, P.A.M. 1983, Sítios arqueológicos numa microrregião alagadiça na Depressão Central do Rio Grande do Sul. Revista do CEPA (Santa Cruz do Sul), 10(12): 1-96. (in Portuguese) ("archaeological sites in a swampy microregion in Rio Grande do Sul Central Depression”)

Ribeiro, P.A.M., Klamt, S.C., Buchaim, J.J.S. \& Ribeiro, C.T. 1989, Levantamentos arqueológicos na encosta do planalto entre o vale dos rios Taquari e Caí, RS, Brasil. Revista do CEPA (Santa Cruz do Sul), 16(19): 49-89. (in Portuguese) (“Archaeological surveys on the slopes of the plateau between the valley of the rivers Taquari and Caí, RS, Brazil”)

Ribeiro, P.A.M. \& Ribeiro, C.T. 1999, Escavações Arqueológicas no Sítio RS-TQ-58: Montenegro, RS, Brasil. Série Documento (Editora da FURG), 10: 1-86. (in Portuguese) (“Archaeological excavations at the site RS-TQ-58: Montenegro, RS, Brazil”)

Rohlf, F. 2015, Tps Serie Softwares. New York: Department of Ecology and Evolution, State University of New York Stony Brook. URL: http://life.bio.sunysb.edu/morph/ Visited: 11 February 2016

Rohlf, F.J. \& Bookstein, F.L. 1990, Proceedings of the Michigan Morphometrics Workshop. Special Publ. No. 2, The University of Michigan Museum of Zoology, 380 p.

Rosa, A.O. 2009, Análise Zooarqueológica do Sítio Garivaldino (RS-TQ-58), Município de Montenegro, RS. Pesquisas Antropologia, 67: 133-171. (in Portuguese)

(“Zooarchaeological analysis of Garivaldino site (RS-TQ-58), Montenegro, RS”)

Sackett, J.R. 1985, Style and ethnicity in the Kalahari: A reply to Wiessner. American Antiquity, 50: 154-159. doi:10.2307/280642

Saragusti, I., Karasik, A., Sharon, I. \& Smilansky, U. 2005, Quantitative analysis of shape attributes based on contours and section profiles in artifact analysis. Journal of Archaeological Science, 32(6): 841-853. doi:10.1016/j.jas.2005.01.002

Schmitz, P.I. 1978, Industrias líticas en el sur de Brasil. Estudos Leopoldenses, 14(47): 103132. (in Spanish) ("Lithic industries from Southern Brazil”)

Schmitz, P.I. 1984, Caçadores e coletores do Sul. In: Caçadores e Coletores da Pré-História do Brasil (Schmitz, P.I., Ed.), IAP/Unisinos, São Leopoldo: p. 1-61. (in Portuguese) ("Hunter and gatherers from the South")

Schmitz, P.I. 1987, Prehistoric hunters and gatherers of Brazil. Journal of World Prehistory, 1(1): 53-126. doi:10.1007/BF00974817

Schmitz, P.I. 1991a, Áreas arqueológicas do litoral e planalto do Brasil. Revista do Museu de Arqueologia e Etnologia, 1: 13-20. (in Portuguese) ("Archaeological areas from the coast and highlands of Brazil”)

Schmitz, P.I. 1991b, Migrantes da Amazônia: A Tradição Tupiguarani. Pré-História do Rio Grande do Sul - Documentos, 5: 31-66. (in Portuguese) ("Migrants from Amazon: Tupiguarani tradition”) 
Schmitz, P.I. 1999, A questão do Paleoíndio. In: Pré-História da Terra Brasilis (Tenório, M.C., Ed.), Editora UFRJ, Rio de Janeiro: p. 55-59. (in Portuguese) (“The Paleoindian question”)

Schmitz, P.I. 2010, Caçadores antigos no vale do rio Caí, RS. Pesquisas Antropologia, 68: 79-108. (in Portuguese) (“Ancient hunters from the valley of Caí river, RS”)

Schmitz, P.I., Arnt, F.V., Beber, M.V., Rosa, A.O. \& Rogge, J.H. 2009, Taió, no Vale do Rio Itajaí, SC. O encontro de antigos caçadores com as casas subterrâneas. Pesquisas Antropologia, 67: 185-320. (in Portuguese) ("The meeting of ancient hunters with underground houses”)

Schmitz, P.I., Barbosa, A.S. \& Ribeiro, P.M. 1980, Temas de Arqueologia Brasileira 1 Paleoindio. Vol. 5. Anuário de Divulgação Científica. Universidade Católica de Goiás, Goiânia, 99 p. (in Portuguese) (“Brazilian Archaeology themes 1 - Paleoindian”)

Thulman, D.K. 2012, Discriminating Paleoindian point types from Florida using landmark geometric morphometrics. Journal of Archaeological Science, 39(5): 1599-1607. doi:10.1016/j.jas.2012.01.004

Valeri, C.J., Cole, T.M., Lele, S. \& Richtsmeier, J.T. 1998, Capturing data from threedimensional surfaces using fuzzy landmarks. American Journal of Physical Anthropology, 107(1): 113-124. doi:10.1002/(SICI)1096-8644(199809)107:1<113::AID-AJPA9>3.0.CO;2-O

Velhagen, W.A. \& Roth, V.L. 1997, Scaling of the mandible in squirrels. Journal of Morphology, 232(2): 107-132. doi:10.1002/(SICI)1097-4687(199705)232:2<107::AIDJMOR1>3.0.CO;2-7

Viscosi, V. \& Cardini, A. 2011, Leaf morphology, taxonomy and geometric morphometrics: A simplified protocol for beginners. PLoS One, 6(10): e25630. doi:10.1371/journal.pone.0025630

Wang, W., Lycett, S.J., Von Cramon-Taubadel, N., Jin, J.J.H. \& Bae, C., J 2012, Comparison of handaxes from Bose Basin (China) and the Western Acheulean indicates convergence of form, not cognitive differences. PloS one, 7(4): e35804. doi:10.1371/journal.pone.0035804

Zelditch, M.L., Swiderski, D.L., Sheets, D.H. \& Fink, W.L. 2004, Geometric Morphometrics for Biologists: A Primer. Elsevier, Academic Press, New York. 443 p. 